\title{
Workshop Intersetorial - Método utilizado para a realização de acordos interprocessos no fortalecimento da cadeia cliente fornecedor em três unidades ambulatoriais do interior do estado de SP.
}

Autora: Edilene Regina Simioli | Co-autoras: Angélica Alonso Camargo, Roberta Patrícia Jeuken e Taise Jordão Zanzarini

\section{INTRODUÇÃO}

0 objetivo deste artigo é o de apresentar o modelo adotado para a realização de acordos interprocessos que garantiram o fortalecimento da cadeia cliente -fornecedor em três unidades ambulatoriais localizadas no noroeste do estado de SP, melhorando a gestão de relacionamentos e os processos das unidades.

\section{METODOLOGIA}

Os três ambulatórios são gerenciados pela mesma Organização Social de Saúde e possuem processos alinhados, trabalho este que foi desenvolvido para a implantação de ISO 9001 e ONA. A cadeia cliente fornecedor de uma organização é o encadeamento e a interface de processos, onde se define quem é cliente e quem é o fornecedor de cada processo. A marca das relações entre cliente e fornecedor é a interdependência e, por consequência, a vulnerabilidade às decisões e ações das partes à disposição de aceitar a vulnerabilidade. MAYER; DAVIS; SCHOORMAN, 1995.

A dificuldade encontrada no desenvolvimento dos acordos estava no alinhamento dos critérios para cada interface. Era necessário definir um modelo que garantisse a participação de todos os envolvidos e que trouxesse a oportunidade de discussão de cada interface, e principalmente, criasse uma relação de confiança entre clientes e fornecedores. 0 método definido foi o de realizar workshops que ofereceriam um momento de reflexão das atividades, discussão "olho-no-olho" entre as partes e culminaria nas propostas de critérios e acordos.

\section{RESULTADOS}

0 resultado foi avaliado como muito bom entre as lideranças, pois todos puderam apresentar seu processo e sugerir prazos e critérios de entrega de seus serviços aos clientes e fazer exigências aos seus fornecedores internos. As propostas foram validadas por todos presentes através de discussão direta e os critérios redefinidos. No término, com todos critérios alinhados, foram preenchidos acordos formais onde foram assinados por todos os participantes confirmando o compromisso com as entregas de seus serviços no prazo e na qualidade definida. Durante todo 0 ano os acordos são monitorados e qualquer quebra de contrato é registrada. As mensurações comprovam o compromisso das equipes com a entrega de resultados dentro do definido pela cadeia.

\section{CONCLUSÃO}

Anualmente é realizado uma edição do workshop para rediscussão dos critérios e apresentação de boas práticas. A cada ano é percebida a evolução e amadurecimento das discussões. Os processos ficam mais robustos e a tomada de decisão a partir deste resultado é factível.
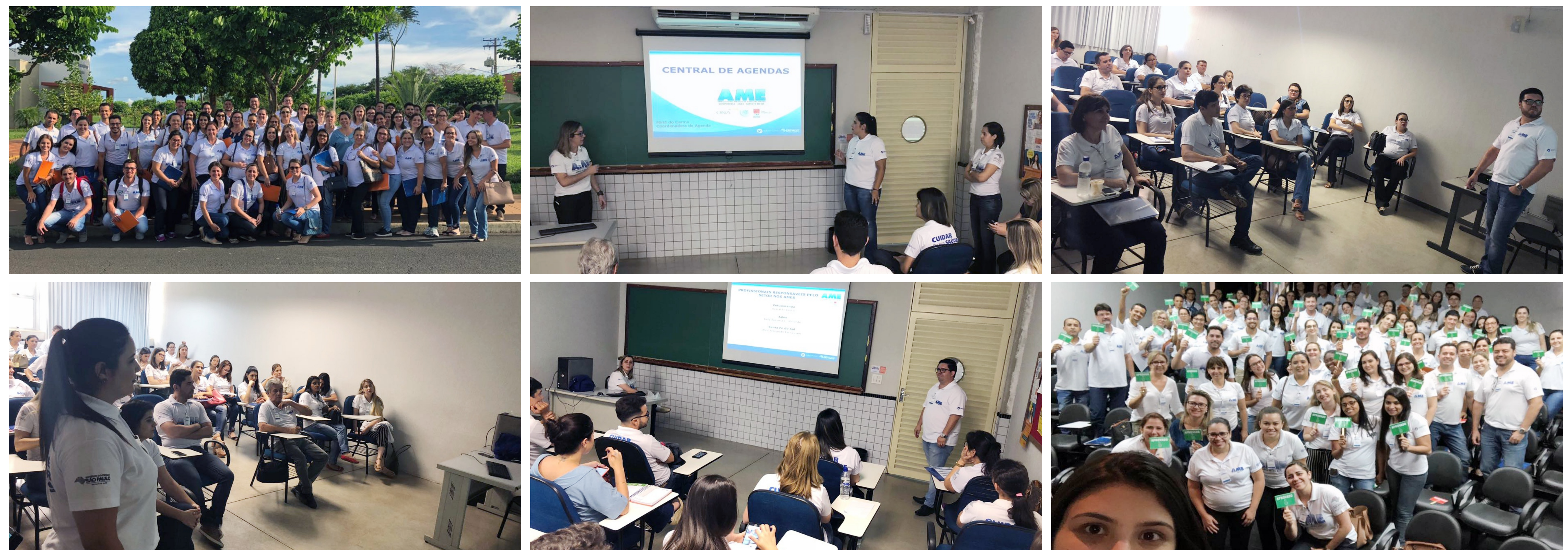

\section{REFERÊNCIA}

MAYER, R. C.; DAVIS, J. H.; SCHOORMAN, F. D. An integrative model of organizational trust. Academy of Management Review, v. 20, n. 3, p. 709-734 